\title{
PENERAPAN PENILAIAN AUTENTIK KURIKULUM 2013 PADA MATA PELAJARAN MATEMATIKA DI MA MUHAMMADIYAH 1 MALANG
}

\author{
Baiduri', Dwi Priyo Utomo², Alfiani Athma Putri Rosyadi ${ }^{3}$, Anis Farida Jamil ${ }^{4}$ \\ ${ }^{1}$ Pendidikan Matematika, Universitas Muhammadiyah Malang, baiduriumm@gmail.com \\ 2Pendidikan Matematika, Universitas Muhammadiyah Malang, dwipuumm@yahoo.com \\ ${ }^{3}$ Pendidikan Matematika, Universitas Muhammadiyah Malang, athmaputri@gmail.com \\ ${ }^{4}$ Pendidikan Matematika, Universitas Muhammadiyah Malang, anisfaridaj@gmail.com
}

\begin{abstract}
ABSTRAK
Abstrak: Kegiatan ini bertujuan untuk mendeskripsikan penerapan penilaian autentik kurikulum 2013 pada mata pelajaran matematika. Jenis penelitian yang dilakukan adalah penelitian kualitatif dengan sifat penelitian adalah penelitian deskriptif kualitatif. Teknik pengumpulan data adalah observasi, dokumentasi, dan wawancara. Teknik analisis data pada penelitian ini menggunakan air flow model yang terdiri dari mereduksi data, menyajikan data, dan menyimpulkan data. Hasil kegiatan berlangsung diawali dengan kegiatan observasi. Selanjutnya terdapar 4 kegiatan yang dilaksanakan yaitu: 1) mengkaji konsep kurikulum 2013 terutama konsep penilaian auntentik kurikulum 2013, 2) diskusi dengan guru matematika tentang rencana implementasi penilaian autentik kurikulum 2013, 3) implementasi penilaian autentik kurikulum 2013, dan 4) refleksi implementasi penilaian autentik kurikulum 2013. Rekomendasi untuk kegiatan yang selanjutnya adalah dikembangkan implementasi untuk pengembangan perangkat pembelajaran berdasarkan kurikulum 2013.
\end{abstract}

Kata Kunci: Penilaian Autentik, Kurikulum 2013, Matematika.

Abstract: This activity aims to describe the application of authentic assessment of the 2013 curriculum in mathematics subjects. The type of research conducted is qualitative research with the nature of research is descriptive qualitative research. Data collection techniques are observation, documentation, and interviews. Data analysis technique in this research using air flow model consisting of reducing data, presenting data, and concluding data. The results of the activity begins with observation activities. The next four activities are: 1) reviewing the concept of curriculum in 2013, especially the concept of axis curriculum assessment 2013, 2) discussion with math teacher about the implementation plan of authentic assessment of curriculum 2013; 3) implementation of authentic assessment of curriculum 2013; and 4) reflection of authentic assessment implementation curriculum 2013. Recommendations for further activities are developed for the implementation of development of learning devices based on the curriculum 2013.

Keywords: Authentic Assessment, Curriculum 2013, Mathematics

Riwayat Artikel: Diterima: 10-12-2017, Disetujui: 13-12-2017 


\section{A. LATAR BELAKANG}

Perubahan KTSP 2006 ke Kurikulum 2013 meliputi 4 elemen yaitu perubahan pada Standar Kompetensi Lulusan (SKL), Standar Isi, Standar Proses, dan Standar Penilaian (Kemendikbud, 2013). Pada KTSP 2006, SKL diturunkan dari Standar Isi sehingga penekanannya lebih banyak pada aspek pengetahuan. Pada Kurikulum 2013, SKL diturunkan dari kebutuhan, sehingga dirinci menjadi SKL Sikap, SKL Pengetahuan dan SKL Keterampilan, karena tiga aspek inilah yakni sikap, pengetahuan dan keterampilan yang dibutuhkan oleh masyarakat dan dunia kerja. Adapun pengaruh terhadap perubahan yang terjadi pada Standar Penilaian bahwa pada KTSP 2006 penilaian lebih menekankan pada aspek pengetahuan, sedangkan penilaian pada Kurikulum 2013 meliputi tiga aspek yaitu penilaian sikap, pengetahuan, dan keterampilan sesuai SKL yang ingin dicapai. Hal tersebut menunjukkan bahwa penilaian dalam Kurikulum 2013 pendekatan utamanya adalah penilaian autentik.

Penilaian autentik sesuai dengan ketentuan Peraturan Menteri Pendidikan Nasional Nomor 22 tahun 2006 dan Permendikbud Nomor 66 Tahun 2013. Penilaian autentik memiliki relevansi kuat terhadap pendekatan ilmiah dalam pembelajaran pada Kurikulum 2013. Kurikulum 2013 mempertegas adanya pergeseran dalam melakukan penilaian yakni penilaian melalui tes berdasarkan hasil saja menuju penilaian autentik dimana mengukur sikap, keterampilan, dan pengetahuan berdasarkan proses dan hasil (Kunandar, 2013).

Kegiatan pembelajaran selalu diakhiri dengan penilaian yang dilakukan oleh pendidik. Hal ini menuntut pendidik untuk mengetahui dan dapat melakukan kegiatan penilaian sesuai dengan tuntutan Kurikulum 2013 yakni melaksanakan penilaian autentik terhadap peserta didiknya. Pendidik harus memahami karakteristik penilaian autentik antara lain: 1) penilaian merupakan bagian dari proses pembelajaran, 2) penilaian mencerminkan hasil proses belajar pada kehidupan nyata, 3) menggunakan bermacam-macam instrumen, pengukuran, dan metode yang sesuai dengan karakteristik dan esesnsi pengalman belajar, dan 4) penilaian harus bersifat komprehensif dan holistic yang mencakup semua aspek dari tujuan pembelajaran (Burhan, 2011).

Perubahan paradigma pendidikan menuju Kurikulum 2013 mendatangkan masalah bagi pendidik dalam proses pembelajaran dan penilaian. Pendidik merasa kebingungan dalam proses penilaian yang dapat memberikan gambaran yang utuh mengenai sikap, keterampilan, dan pengetahuan peserta didik dikaitkan dengan kehidupan nyata mereka serta bagaimana format penilaiannya. Berdasarkan hasil observasi dan wawancara terhadap pendidik khususnya guru matematika di MA Muhammadiyah 1 Malang diperoleh informasi bahwa pendidik mengalami kesulitan dalam menyusun instrumen penilaian autentik dan menerapkannya dalam melakukan penilaian proses dan hasil peserta didik yang meliputi penilaian sikap, pengetahuan, dan keterampilan. Oleh karena itu, berdasarkan uraian di atas perlu adanya penelitian untuk mendapatkan informasi secara lebih spesifik dan secara praktik terhadap pendidik di MA Muhammadiyah 1 Malang dalam menerapkan penilaian autentik sesuai dengan tuntutan Kurikulum 2013. 


\section{B. METODE PELAKSANAAN}

Jenis pelaksanaan pengabdian ini dianalisis secara kualitatif. Sedangkan sifat pengabdian ini menggunakan pendekatan deskriptif kualitatif. Sifat deskriptif kualitatif menghasilkan data berupa kata-kata tertulis atau lisan dari orang-orang dan perilaku yang diamati. Pada pengabdian ini mendeskripsikan penerapan penilaian autentik kurikulum 2013 pada mata pelajaran matematika di MA Muhammadiyah 1 Malang.

Teknik pengumpulan data dengan cara observasi, dokumentasi, dan wawancara. Adapun teknik analisis data yang akan digunakan adalah model air (flow model) yang dikemukakan Miles \& Huberman (1992: 24-25) yang meliputi kegiatan (1) mereduksi data, (2) menyajikan data, dan (3) menarik kesimpulan.

Permasalahan utama yang dihadapi sekolah atau guru matematika MTs Muhammadiyah 1 Malang adalah berkaitan dengan kurangnya informasi tentang penilaian autentik berdasarkan kurikulum 2013. Berkenaan dengan hal tersebut, usulan kegiatan pengabdian ini adalah memberikan pendampingan penyusunan penilaian autentik berdasarkan kurikulum 2013.

1. Mengkaji Kurikulum 2013

2. Diskusi tentang penyusunan draft pendampingan penyusunan penilaian autentik di MTs Muhammadiyah 1 Malang.

3. Pendampingan penyusunan penilaian autentik di MTs Muhammadiyah 1 Malang

4. Refleksi kegiatan penyusunan penilaian autentik di MTs Muhammadiyah 1 Malang

\section{HASIL DAN PEMBAHASAN}

Berdasarkan hasil pengabdian ini diperoleh data dari setiap kegiatan antara lain sebagai berikut.

\section{Observasi}

Pada hari rabu, tanggal 26 April 2017 kegiatan observasi adalah kegiatan yang pertama kali dilakukan. Observasi dilakukan untuk mengetahui permasalahan yang ada di MA Muhammadiyah 1 Malang. Hasil observasi diperoleh bahwa MA Muhammadiyah 1 Malang belum menggunakan penilaian autentik K13 yang seharusnya sudah diterapkan sesuai Kurikulum 2013. Berdasarkan hasil wawancara dengan guru matematika yang berjumlah 3 orang di MA Muhammadiyah 1 Malang diperolah informasi bahwa guru belum memahami konsep penilaian autentik K13 dan bagaimana bentuk formatnya.

2. Mengkaji Kurikulum 2013 terutama mengenai konsep penilaian autentik kurikulum 2013

Kegiatan PPDS selanjutnya dilakukan pada hari Jumat tanggal 26 April 2017. Pada kegiatan ini, tim mengadakan rapat untuk membicarakan hasil observasi yang dilakukan sebelumnya. Masalah yang diperoleh adalah kurangnya pengetahuan guru mengenai konsep penilaian autentik dan guru belum melakukan penilaian yang sesuai denga kurikulum 2013 yaitu penilaian autentik. Pada rapat ini, tim mengkaji konsep penilaian autentik yang memperoleh hasil analisis 
Kompetensi Dasar (KD) dari Kompetensi Inti (KI) yang akan digunakan dalam pembelajaran. Dalam menganalisis KD dari KI melalui langkahlangkah sebagai berikut:

a. Analisis KD dari KI Pengetahuan

Analisis KD dari KI pengetahuan meliputi: 1) mengembangkan indikator tercapainya KD, 2) menentukan materi pembelajaran, 3) menentukan tujuan pembelajaran yang ingin dicapai, 4) menentukan metode, strategi, dan model pembelajaran yang akan digunakan,dan 5) menentukan bentuk dan instrumen penilaian yang akan digunakan.

b. Analisis KD dari KI Keterampilan

Analisis KD dari KI keterampilan menyesuaikan hasil analisis KD dari KI pengetahuan. Misalkan KD dari KI pengetahuannya adalah "menyelesaikan sistem persamaan linier dua variabel" maka KD dari KI keterampilan yang bersesuaian adalah "mempresentasikan hasil penyelesaian sistem persamaan linier dua variabel".

c. Analisis KD dari KI Sikap (Spiritual dan Sosial)

Setelah menentukan KD dari KI pengetahuan dan KD dari KI keterampilan, selanjutnya menentukan $\mathrm{KD}$ dari $\mathrm{KI}$ sikap yang sesuai untuk diintegrasikan dalam pembelajaran tersebut. Selanjutnya tim merancang RPP sesuai dengan konsep K13. RPP memenuhi langkahlangkah pembelajaran scientific yang terdiri dari $5 \mathrm{M}$ yaitu Mengamati, Menanya, Mengumpulkan data, Mengasosiasi, dan Menyimpulkan. Selanjutnya melengkapi dengan format penilaian autentik K13 yaitu instrumen penilaian tes tertulis (kognitif), sikap (afektif) dan keterampilan (psikomotorik).

Contoh format penilaian Kognitif (Pengetahuan)

TABEL 1

CONTOH FORMAT PENILAIAN

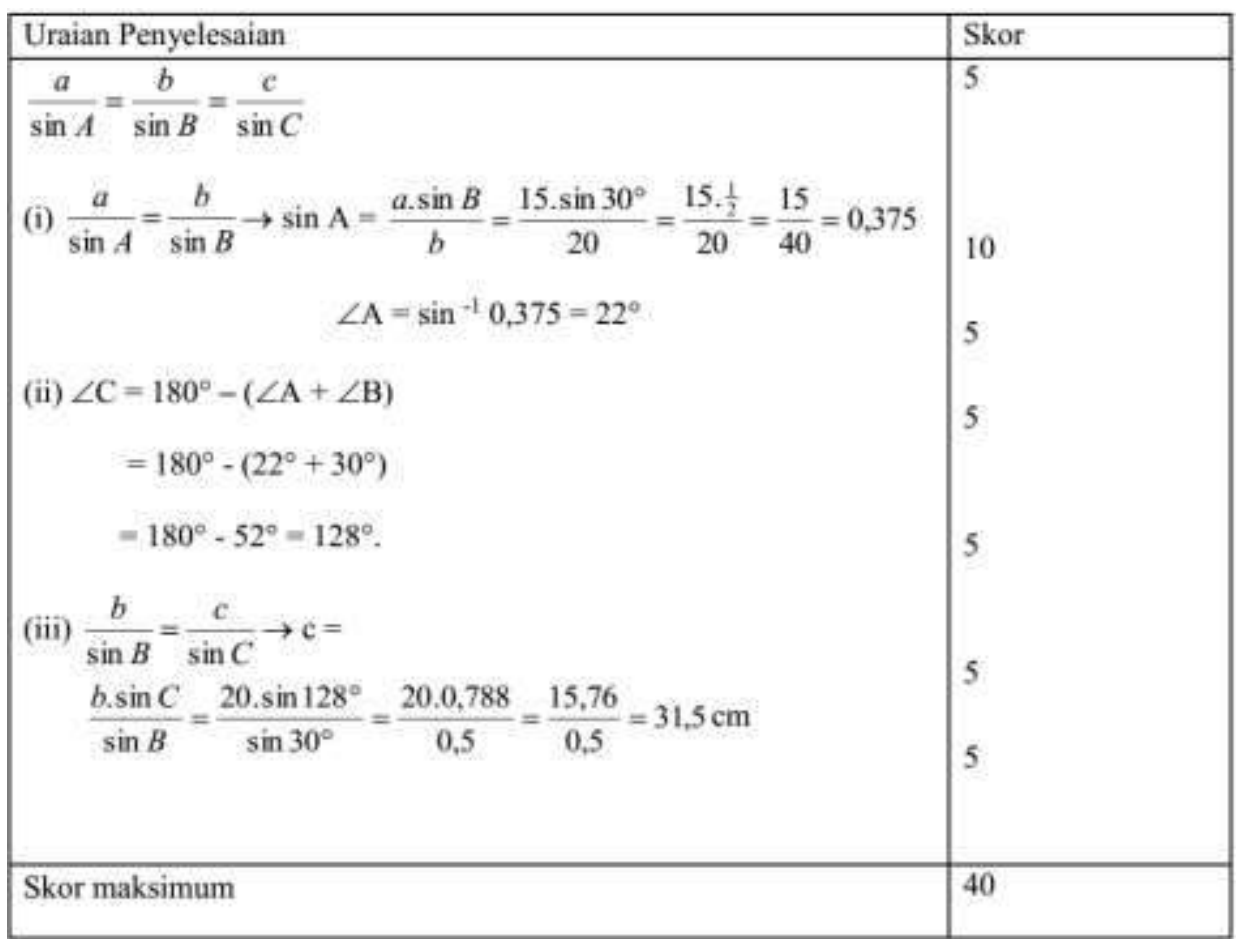


Contoh format penilaian keterampilan (psikomotorik):

TABEL 2

CONTOH FORMAT PENILAIAN KETERAMPILAN

\begin{tabular}{|l|l|l|l|l|l|l|}
\hline \multirow{2}{*}{ No } & \multirow{2}{*}{ Nama Siswa } & \multicolumn{3}{|c|}{ Skor tiap aspek } & Jumlah & \multirow{2}{*}{ Nilai } \\
\cline { 3 - 7 } & & a & b & c & Skor & Nian \\
\hline & & & & & & \\
\hline & & & & & & \\
\hline
\end{tabular}

Keterangan:

$\mathrm{a}=$ Kejelasan dan kebenaran makalah

$\mathrm{b}=$ Kemampuan mempresentasikan

$\mathrm{c}=$ Kelengkapan materi yang dibahas

Contoh Format Penilaian Sikap (Afektif)

TABEL 3

CONTOH FORMAT PENILAIAN SIKAP (AFEKTIF)

\begin{tabular}{|l|l|l|l|l|l|l|}
\hline \multirow{2}{*}{ No } & \multirow{2}{*}{ Nama Siswa } & \multicolumn{3}{|c|}{ Skor tiap aspek } & \multirow{2}{*}{$\begin{array}{c}\text { Jumlah } \\
\text { Skor }\end{array}$} & \multirow{2}{*}{ Nilai } \\
\hline & & Jujur & Disiplin & $\begin{array}{c}\text { Tanggung } \\
\text { Jawab }\end{array}$ & S & \\
\hline & & & & & & \\
\hline & & & & & & \\
\hline
\end{tabular}

3. Diskusi dengan guru matematika tentang rencana implementasi penilaian autentik kurikulum 2013

Pelaksanaan diskusi dengan guru pada tanggal 6 Mei 2017 di Laboratorium Prodi Matematika pada pukul 8.00 - 12.00. Diskusi dihadiri oleh tim PPDS yaitu ( Dr. Baiduri, M.Si, Dr. Dwi Priyo Utomo, M.Pd, Alfiani Athma Putri Rosyadi, M.Pd, dan Anis Farida Jamil, M.Pd). Sedangkan guru yang hadir yaitu dua orang guru matematika MA Muhammadiyah 1 Malang yaitu Bapak Ary dan Ibu Basnah.

Dari hasil diskusi dengan dua orang guru matematika diperoleh beberapa hal yaitu:

a. Guru kurang informasi tentang format penilaian autentik sesuai dengan kurikulum 2013. Hal ini dikarenakan minimnya informasi terkait dengan kurikulum 2013 dan

b. Guru kesulitan menerapkan penilaian siswa sesuai penilaian autentik kurikulum 2013.

c. Guru mendapatkan informasi mengenai konsep penilaian autentik K13 dan contoh format penilaian autentik K13 


\section{Implementasi penilaian autentik kurikulum 2013 mata pelajaran matematika.}

Pelaksanaan pembelajaran pada tanggal 24 Juni 2017. Materi yang disampaikan adalah trigonometri. Kegiatan yang dilakukan adalah guru menerapkan konsep penilaian autentik K13 pada pembelajarannya di kelas dengan didampingi oleh tim. Indikator pada

a. Menjelaskan aturan sinus dan cosinus

b. Peserta didik mengingat konsep

c. perbandingan trigonometri untuk sembarang segitiga siku-siku

d. Peserta didik dapat membedakan perbandingan trigonometri untuk sembarang segitiga siku-siku

e. Peserta didik dapat menentukan konsep aturan sinus

f. Peserta didik dapat menentukan konsep aturan cosinus

g. Menyelesaikan masalah yang berkaitan dengan aturan sinus dan cosinus

h. Menerapkan konsep aturan sinus dalam menyelesaikan masalah.

i. Menerapkan konsep aturan cosinus dalam menyelesaikan masalah

Selama proses pembelajaran, secara keseluruhan, siswa memperhatikan dengan baik meskipun ada beberapa siswa yang tidak memperhatikan. Sesekali guru juga berkeliling kelas untuk mengetahui bagaimana aktivitas siswa yang ada di kelas. Guru mengisi lembar penilaian yang sudah disusun sebelumnya.

\section{Refleksi Implementasi penilaian autentik kurikulum 2013 mata pelajaran matematika.}

Kegiatan terakhir yang dilakukan pada program ini adalah refleksi kegiatan implementasi penilaian autentik kurikulum 2013 mata pelajaran matematika di MA Muhammadiyah 1 Malang. Kegiatan ini melibatkan mahasiswa dalam menganalisis RPP yang telah dibuat oleh guru matematika MA Muhammadiyah 1 Malang. Keterlibatan mahasiswa bertujuan untuk memberikan pembelajaran mengenai perangkat pembelajaran yang baik sesuai dengan K13 khususnya mengenai penilaian autentik K13. Hasil refleksi menunjukkan bahwa RPP yang dibuat telah mengikuti langkah-langkah scientific 5M. Namun, penilaian autentik yang dibuat hanya pada penilaian kognitif (pengetahuan) dan keterampilan (psikomotorik) sedangkan penilaian sikap (afektif) tidak ada.

\section{SIMPULAN DAN SARAN}

Kegiatan berlangsung diawali dengan kegiatan observasi. Selanjutnya terdapar 4 kegiatan yang dilaksanakan yaitu: 1) mengkaji konsep kurikulum 2013 terutama konsep penilaian auntentik kurikulum 2013, 2) diskusi dengan guru matematika tentang rencana implementasi penilaian autentik kurikulum 2013, 3) implementasi penilaian autentik kurikulum 2013, dan 4) refleksi implementasi penilaian autentik kurikulum 2013. Rekomendasi untuk kegiatan yang selanjutnya adalah dikembangkan implementasi untuk pengembangan perangkat pembelajaran berdasarkan kurikulum 2013. 
Saran untuk pengabdian berikutnya adalah diperlukan pendampingan untuk penyusunan perangkat pembelajaran lain dalam menerapkan kurikulum 2013. Selain itu diperlukan pelatihan dan pendampingan terhadap guru dalam menerapkan kurikulum 2013 agar berjalan sesuai dengan tujuan yang diharapkan.

\section{DAFTAR RUJUKAN}

[1] Anonim, Undang-undang No. 14 Tahun 2005 tentang Guru dan Dosen. Peraturan Menteri Pendidikan Pendidikan dan Kebudayaan, 2005.

[2] Garofalo, J., \& Lester, Jr., F.K. Metacognition, cognitive monitoring, and mathematical performance. Journal for Research in Mathematics Education,16, pp. 163-176. 1985

[3] Hembree, R. Experiments and relational studies in problem solving: A metaanalysis. Journal for Research in Mathematics Education, 23, h. 242-273, 1992.

[4] Nurgiayanoro, Burhan. Penilaian Otentik. Jakarta: GMUP, 2011

[5] Kemendikbud. Konsep Kurikulum 2013 (Materi Pelatihan Implementasi Kurikulum 2013). Jakarta: BPSDMPK dan PMP Kemendikbud. 2013

[6] Kunandar. Penilaian Autentik (Penilaian Hasil Belajar Peserta Didik Berdasarkan Kurikulum 2013). Jakarta: Rajawali Press. 2013 